Animal Health Research Institute

Assiut Regional Laboratory

Director Prof. Dr. S.M. Nashed

\title{
BOVINE MASTITIS \\ (AGE, CAUSES AND CONTROL) \\ IN ASSIUT GOVERNORATE
}

(With 4 Tables and 4 Figures)

\author{
By \\ S. R. SEDDEK
}

(Received at 21/9/1996)

التهاب الضرع فى الابقار فى محافظة أسبوط - الاسباب - الوقاية )

صديت رشوان

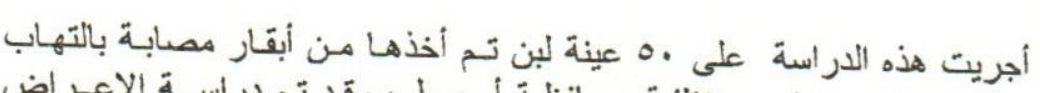

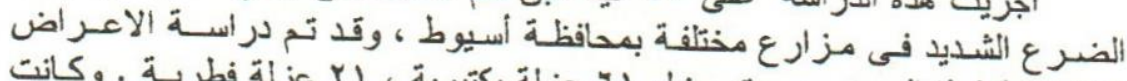

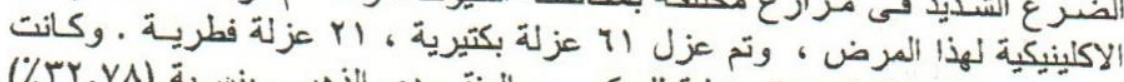

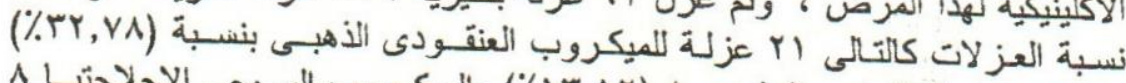

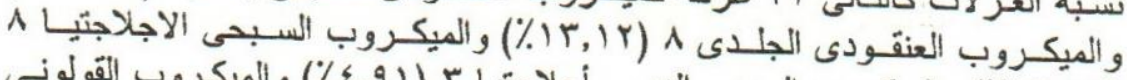

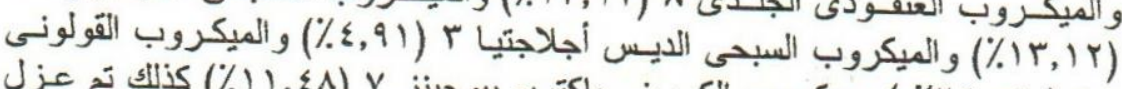
10 10

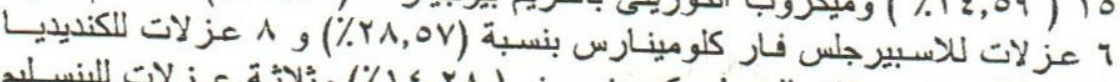
1)

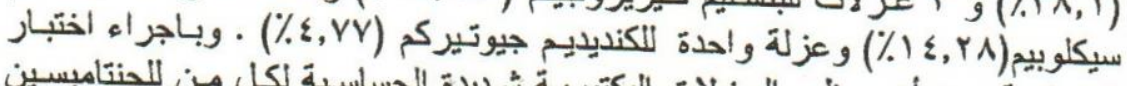

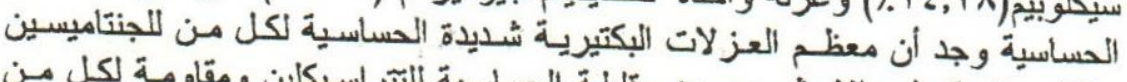

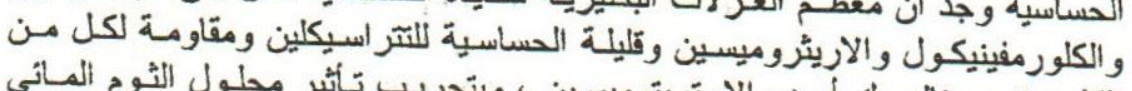

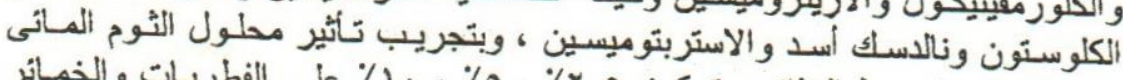

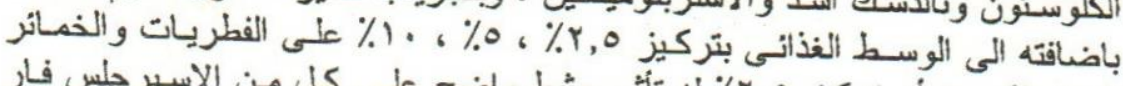

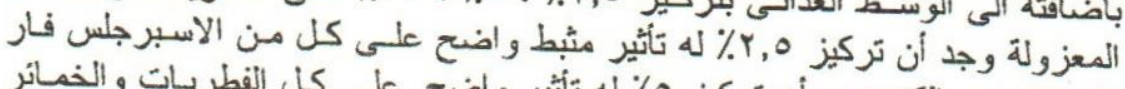

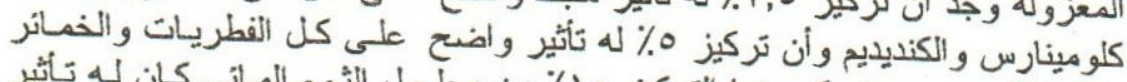

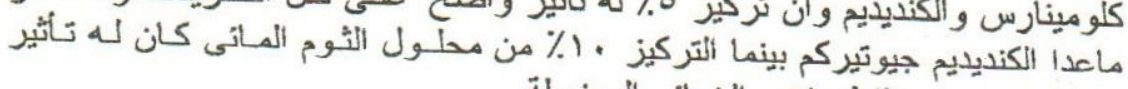
مثبط على جميع الفطريات والخماتر المعزئرولة. 


\section{SUMMARY}

This study was carried out on 50 cows clinically affected by acute mastitis in different farms in Assiut Governorate. The clinical symptoms of affected animals have been discussed. The isolated organisms in this study were 61 bacterial isolates and 21 isolates of yeast and fungi, the percentage of bacterial isolates in total infected cases were Staphylococcus aureus 20 (32.78\%), Stophylococcus epideramidis $8(13.12 \%)$ Streptococcus aglactiae $8(13.12 \%)$. Streptococcus dysaglactae 3(4.91\%) E.coli $15(24.59 \%)$ and $C$. pyogens $7(11.48 \%)$. The isolated yeast and fungi were Aspergillus flavous 6(28.57), Pencillium chrysogemum 3(14.28\%) Pencillium cyclopium 3(14.28), Candida speices $8(38.1 \%)$ and Geotricum Candidium $1(4.77 \%)$. Sensitivity test was carried out by different types of antibiotics, the most isolated bacterial organisms were higtly sensitive to Gentamycine, Chlormphinicol and Erthromycine while they were less sensitive to Tetracycline and resistant to Colistome, Naldizie Acid and Streptomycine. Aquous Garlic solution was experminted to determine its effect on isolated yeast and fungi by using different concentration $(2.5 \%, 5 \%$ and $10 \%)$ of Garlic solution. It was found that $2.5 \%$ of Garlic is effective on Aspergillus and Candida sp, 5\% more effective on all species except Geotericum Candidium, while 10\% concentration causes complete inhibition for all types of fungus and yeast isolates.

Key words: Bovine masitis in Assiut

\section{INTRODUCTION}

Mastitis is of a great economic importance in farm animals. The disease remains one of the most important causes of tremendous loss in milk yield in many countries. The economic significance of the disease varies among herds and to some extent depends on the system of management and the degree of intensification (Blood et al., 1983), it reduces production of milk with an average $225 \$$ per caw each year (Philip, 1991). In addition mastitis may have some public health importance scince 
occasionally milk harbouring human pathogens may cause infection to consumers of raw or inadequately heated milk.

In concerning clinical symptoms the affected animal suffering from a rise of body temprature, swelling of udder, hotness, hardness, some times the animal refused the food. the scereted milk becomes watery, cloted, gelatenious and some times tinged with blood or bloody (Zaitoun et al., 1991 and Naser and Abdel-Moghney, 1994).

The main causitive agents of mastitis were Staphylococcus aureus followed by E.coli, Streptococcus species and Corynebacterium pyogens (Waage and Aursio, 1992) and Ameh et al. (1993). Mycotic mastitis in dairy caw, either alone or in association with other pathogens has gained importance in recent years. Various fungi including Aspergillus niger, Aspergillus nidulans, Aspergillus terrus, Cladosporum species, Pencillium species as well as Candida species are frequently associated with bovine mastitis (Misra and Panda, 1986).

In case of treatment and antimicrobial activity Char et $\underline{\text { al }}$. (1993) revealed that $(85.38-90.8 \%)$ of bacterial isolates were sensitive to Gentamycine and Chlorumphenicol while pencillin was the least effective.

* From the previously mentioned the aim of the present work was the isolation and identification of bacterial or mycotic causitive agents of bovine mastitis.

* Antimicrobial activity and treatment of affected mimals.

\section{Animals:}

\section{MATERIAL and METHODS}

This study was carried out on 50 caws clinically affected with acute mastitis, these animals were classified according to age to 3 groups:

A) First group (21) Animals aging between 21/2-4 years).

B) Second group (14 Animals aging between 4-6 years).

C) Third group (15 Animals aging above 6 years).

\section{Collection of Samples:}

Milk samples were collected aspetically according to the known routine procedure. The udder was throughly washed with running water and dried with clean towel, then the teats sprayed with $70 \%$ ethonol. After that the first few squirts of milk was 
discarded then $5 \mathrm{ml}$ of milk samples from each quarter was collected in a sterile McCarteny bottle. All samples were cooled at $\left(4^{\circ} \mathrm{C}\right)$ and transported to the laboratory.

The milk samples were activated by incubation for 12 hours at $37^{\circ} \mathrm{C}$. Then milk samples centerifugated at $300 \mathrm{RPM}$ for $30 \mathrm{M}$. before bacteriological cultivation.

\section{Isolation and Identification:}

\section{A) Bacterial causes:}

$10 \mathrm{ul}$ from milk samples was streaked on the surface of a blood agar plate and MacConkeys agar plate and incubated at $37^{\circ} \mathrm{C}$ for $48 \mathrm{hrs}$. Purified isolates were identified according to their different feature which included, morphological, biochemical characters, Cown and Steel (1973), Chruichshank et al., (1975) Coles (1986) and Collee, et al. (1989).

\section{B) Fungal causes:}

Part of the centrifugated milk samples was cultured on Sabourad's dextrese agar (Moss and Mcquown, 1979) containing Chlormphenicol and Cyclohexamide $(0.5 \mathrm{~g} / \mathrm{L}$ for each) to inhibit the bacterial growth and to minimize the development of some sapraphytic fungi. Cultured plates were incubated at $25^{\circ} \mathrm{C}$ and examined daily until growth become evident.

Identification of fungal colonics was made depending on macroscopic appearance of fungal colonies, colour, and microscopic characters (Shape and dimensions of Condia and chlamydospores, mode of hyphal branching) (Raper and Feenel, 1965 and Frey et al., 1979).

The antibiogram of the isolated organisms were applied using several types of antibioties by disc diffusion method described by Stokys, (1986). These antibiotics were Gentamycine (10 ug), Erthromycine (10 ug), Chlormphinicol (30 ug). Rifampicine (30 ug), Teteracycline (30 ug), Ampicillin (10 ug), Flumaquine (30 ug), Colistone (10 ug), Naldizic acid (30 ug) and Streptomycine (10 ug).

In refering to yeast and mycotic isolates. The isolates were inoculated in S.D.A. plates containing $(2.5 \%),(5 \%)$ and $(10 \%)$ Garlic aquous solution and incubated at $28^{\circ} \mathrm{C}$ till the colonial groth become evident. The degree of inhibition was compared to control one. 


\section{RESULTS}

The obtained results were tabulated in Tables $1,2,3 \& 4$ and Figures 1, 2, $3 \& 4$.

\section{DISCUSSION}

Mastitis or inflammition of the udder has a direct effect on the quality and quantity of milk, the main clinical signs of mastitis were painful swelling, hotness, hardness of udder, rise of body temprature and reduced milk yeilds. the mastitic milk of infected quarter was pale and yellowish in colour in E.coli infection and blood or tinged with blood in Staphylococcus aureus, in case Streptococcus sp., the milk was gelatensous with clots, while in Corynebacterium the milk contained pus and straw yellow and mucoid in mycotic infection. These clinical symptoms in agreement to that mentioned by Zaitoun et al. (1991) and Nasar and AbdelMoghney (1994).

In the Table (1). The obtained results cleared that the main bacterial isolates were Staphylococcus aureus, E.coli, Staphylococcus epidermidis, Streptococcus aglactiae, Streptococcus dysaglactiae and Corynebacterium pyogens their percentage in total infection were $20(32.78 \%), 15(24.59 \%)$, $8(13.12 \%), 8(13.12 \%) 3(4.91 \%)$ and $7(11.48 \%)$ respectively. These results were nearly semillar to that previously mentioned by Ahmed et al., (1988), Ameh et al., (1993) Kothe et al. (1993), Waage and Aursio (1992) and Chotiah (1993), while, Ibtsam et al. (1993) stated that the predominant organisms were Staphylococcus aureus, Staphylococcus epidermidis and E. coli with Lesser percentage $(23.56 \%),(9.77 \%)$ and $(6.32 \%)$ respectively.

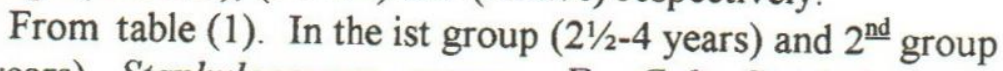
(4-6 years) Staphylococcus aureus, E. Coli, Staphylococcus epidermidis, and Streptococcus agalactiae represent the main causitive agents and were isolated with high percentage (35.48$31.25 \%)$, (25.91-25\%), (16.13-12.5\%) and (12.90-18.75\%) respectively in comparing with lesser percentage in $3^{\text {rd }}$ group above 6 years $(18.58 \%),(21.42 \%),(7.14 \%)$ and $(7.14 \%)$. This results insure that IMI (Interamammary infection) increased in age 
between $2 \frac{1}{2-4}$ years in $1^{\text {st }}$ and $2^{\text {nd }}$ group (4-6 years) and decline above 6 years ( $3^{\text {rd }}$ group).

These results were nearly semillar to that recorded by Rober et al. (1994), Coasta et al. (1994), Fox et al. (1995) and Lescort, et al. (1995) whose mentioned that Staphylococcus aureus, E. Coli, Staphylococcus sp., and Streptococcus aglactia were the most prevelant causitive agent at early age.

Smith (1983); Waagee and Aursio (1992) and Nickroson et al. (1995) isolated Staphylococcus epidermidis and E. coli from clinically affected dairy heifers at breeding age (2-5 years) and their percentage were $(15 \%)$ and $(24 \%)$ respectively. These results were nearly semilar to that recorded in this study in $1^{\text {st }}$ and $2^{\text {nd }}$ group.

From this study, the presence of mixed infection mainly Staphylococcus auraus, staphylococcus epidermidis with E. coli, demonstrate the complexity of the disease and this result agree to that obtained by Jain (1979) who stated that Staphylococcus aureus may predispose the dairy herd to infection by coliform organisms or other pathogens.

The high incidence of Staphylococcus aureus and E. coli may be attributed to heavy contamination of bedding, housing, food matenals, water, air and equipments. Also Staphylococcus aureus was isolated from teat skin, external onfices of teats and teat canal before and after parturition. Also Staphyloccous aureus has wide spreading among seasonal year except summer. the over crowded, increase housing time, and increase the moisture, humidity increase IMI with E.coli pathogens, this was supported by Roberson et al. (1994).

The high incidence of Corynebacterium pyogens $(28.58 \%)$ in $3^{\text {rd }}$ group incompared to lower percent in $1^{\text {st }}$ and $2^{\text {nd }}$ group $(6.45-6.25 \%)$ attributed to that most of these samples were taken in summer and later age of animals, this was supported by Untermann (1965), Yass et al. (1983) and Waage and Aursio (1992) whose mentioned that the prevalance of IMI with Corynebacterium pyogens increased with laction number (9 lactnumber) and age of animal up to (9-10 years).

Our results cleared that lower incidence of Streptococcus agalactiae in $1^{\text {st }}$ and $2^{\text {nd }}$ group $(12-90,18.75)$ agree to that 
obtained by Schukken et al. (1993) who mentioned that Streptococcus agalactiae was fallen in old years.

The results of isolated yeast and fungil pathogens from mastitic milk of caws as identified in table (2) were Aspergillus flavous (28.57\%), Pencillium Chrysogenum (14.28\%), Pencillium cyclopium (14.28\%), Candida sp. (38.1\%) and one isolates of Geotricum Candidium. Aspergillus flavous and Candida sp., represent the main causitive agents of mycotic and yeast mastitis, where Candida $\mathrm{sp}$. isolated in pure culture from 8 cases and Aspergillus isolated in pure culture from 4 clinical cases. These obtained results in table (2) were in agreement to that mentioned by Misra and Banda (1986); Gammoudi et al. (1992); Zaitoun et al., (1991); Kothte et al. (1993) and Guhad et al. (1995).

The high incidence of Candida sp. (44.45\%), pencillium Chrysogenum (22.22\%) and Aspergillus flavous (33.33\%) in $3^{\text {rd }}$ group than that in ${ }^{-\frac{\text { st }}{}}$ and $2^{\text {nd }}$ group insurec that $\mathrm{N}_{-}$. by yeast and fungi decreased in younge age $\left(2 \frac{1}{2}-6\right)$ and increased in later age above 6 years in $3^{\text {rd }}$ group as in Table (2). This agree to that obtained by Sreeramulu et al. (1992) who mentioned that the incidence of mycotic and yeast mastitis increased with age (8-10 years).

The variation in isolated causitive agents (bacterial, fungus and yeast) of acute mastitis were attributed to age of animal, Immune deffensive mechanism of the udder, laction stage, heavy contaminated bedding, season 0 , dirty udder, high line milking machine, wide sprcading of flies among the animal form, and over crowded house Waage and Aursio (1992), Sreeramulu et al. (1992), Bortlett and Miller (1993) and Liebisch, et al. (1994).

In refering to treatment sensitivity was carried out on several types of antibioties using dise diffusion method as in (Table 3). The results indicate that most bacterial isolates Staphylococcus aureus, Staphylococcus epidernndis, Streptococcus agalactiae and Corynebacterium pyogens which represent the major causes of mestitis were highly sensitive to Gentamycine, Erythromycine and Chlormphenicol except Corynebacterium pyegenes which was resistant to Chlormphenicol. Also these organisms were less sensitive To Rifampcine and Ampicilline and Flumaquine and Teteracycline $(30 \mathrm{mg})$ and resistant to Colistone, Naldizic acid and Steptomycine (Table 3). these results were supported by Saxena, 
et al. (1993), Char et al . (1993), Kothe et al., (1993) and Gentilini et al. (1994). The field treatment of infected caw with Gentamaycine for 6 days give good results (more than $90 \%$ of clinical cases were cured). This agree with reported by Saxena et al. (1993) who mentioned that all cows were treated with Gentamycine were cured (100\%). In table (4) both isolated yeast and fungi were Aspergillus flavous, Candida sp., and Penicillium (P. Chrysogemum and P. Cyclopium) which represent the main cause of bovine mycotic mastitis were hightly sensitive to Garlic solution $5 \%$ and $10 \%$ while Candida sp and Aspergillus flavous the most prevalant cause were hightly sensitive to $2.5 \%$ of Garlic solution. These results agree to that obtained by El-Badry and Sokkar (1988), Ziatoun, et al. (1991) and El-Shanawany (1993).

In conclusion, mastitis in dairy form still present one of the commonest and serious diseases, so more efforts must be done to eleminat the accurence of that problem which represent good mongement practices such as milkers hygine, sanitization of milking machine, healthy enviroment as well as controlling the other pridisposing disease should be put in consideration among the major prophylactic measures. Identification of the causitive agent and sensitivity testing are very important in the tratment of mastitis and elemenation of the disease. Also teat dipping with suitable dairy antiseptic and scrubbing of teat orifice with alcohol soaked pad diminshed the prevalance of the disease.

\section{REFERENCES}

Ahmed, A.A.; El-Rashidy, A.A.; Metias, K.N.; El-Garhy, M.M. and Tawfik, M.S. (1988): Out break of bovine mastitis in alarge dairy herd in Egypt. J. Egypt. Vet. Med., Ass; 48 No(2) 169-210.

Ameh, J.A.; Addo, P.B.; Adekeye, J.O.; Gyane, F.O. (1993): Prevalence of clinical mastitis and intrama-mmary infections in Nigerian goats. Preventive veterinary Medicine 17 (1/2) 41-46.

Bartlett, P.C.; Miller, G.Y. (1993): Managerial risk factors for intramammary coagulase-positive staphylococci in ohio dairy herds. Preventive veterinary Medicine 17 (1/2) 3346. 
Blood, D.C.; Radostits, O.M. and Henderson, J. A. (1983): Veterinary Medicine $16^{\text {th }}$ ed., Eastbourne, Bailliere Tindal, pp. 176: 415-472.

Char, N.L.; Rao, M.R.K.; Rajeswri, K.R. (1993): Clinical mastitis in cawsi bacterial and antimicrabial activity. Vet. J. 70(4) 378-379.

Chotiah, S. (1993): Susceptibility of local isolates of staphaurcus and stoph-opidermidis from bovine mastitis milk to pencillin and Ampicillin. Penyakit Hewan 25 (45) 15-19.

Chruichshank, R.; Duguid, J.P.; Mormion, B.R. and Swoin, R.H.A. (1975): Medical Microbiology, $2^{\text {nd }}$ Vol $12^{\text {ed }}$ livingstone, Edinburgh. London and Newyork.

Coles, E.H. (1986): Vet clinical pathology. $4^{\text {th }}$ ed. W. B. Saunders company philadelphia, London, Toronto p. 215.

Collee J.G.; Duguid, J.P.; Fraser A.G. and Marmion. B.P. (1989): Ppartical Medical Microbiology. $13^{\text {th }}$ ed volume (2) eit 4 Rchill Livingstone. Edinburgh London Meibourne and New-York.

Costa, E.O. DA; Benites, N.; Carcioei, A.C.; Melville, P.A.; Prada, M.S.; Ribeiro, A.R.; Watanabe, E. (1994): Study on the etiology of intramammarian infection in dairy cattle. Italy societa volume 1(2) 825-828

Cowan, S.L. and Steel, K.J. (1973): Manual for the identification of Medical Bacteria. Longon, Cambridge, University Press. p. 44.

El-Badry, A.A. and Sokker, I.M. (1988): Mycotic flora of chicken population in kena Governorate. Assiut. Vet. J. 19-38; 174.

El-Shanawany, A.A. (1993): Human dermatophytes in Assiut and New Valley Governorates. Ph. d. thesis Fac. Sci. Assiut Univ.

Fox, L.K. Chester, S.I.; Hallberg, J.W.; Nickerson, S.C.; Pankey, J.W.; Weaver, L.D. (1995): Survey of Intramammary infection in dairy heifers at breeding age and first parturition. Journal of Dairy Science 78(7) 1619-1628.

Frey, D.; Oldfied, R.J. and Bridger, R.C. (1979): Acolour atlas of pathogenic furgi, published by wolfe Medical publication Lt D.; Holand. 
Gammoudi, S.O.; Mohamed, S.M. Azwai, H.M.; Gammeel (1992): Acase of mastitis in a she camel caused by Geotricum candidium. Libyan Vet. Med. J. Vol. I., 134-136.

Gentilini, E.; Denamiel, G.; Perezmonti, H.; Marco, g.; Amoedo, L. (1994): Bouine mastitis; sensitivity profile of staphylo coccus spp. strains by the semiquantitive agar antibiogram method against ten antimierobials. Veterinaria Argentina 11 (105) 314-316.

Guhad, F.A.; Jensen, H.F.; Albak, B.; Rycoraft, A., Hau, J. (1995): A murine model for the study of mycotic mastitis. J. of Comp. Patho. 113(4) 315-325.

Ibtisam, E.; Mohamed G.E. and El-Owni, O.A.O. (1995): Study on the incidence and Etiology of bovine mastitis in Sudan. $2^{\text {nd }}$ Sci. Cong. Egyption Society for Cahle diseases. 327336.

Jain, N.C. (1979): Common mommory pathogens and factors in infection and mastitis. $\therefore$. of dairy science. $62,-28-134$.

Kothe, R.V.; Sherikar, A.A., Milk Herjee, S.R. (1993): Isolation and identification of pathogenic bacteria and fungi associated with mastitis in buffaloes. Indian Journal of Comparative Microbiology Immunology and infectious diseases 14 (314) 47-49 (En. 13 ref.)

Lesort, F., Coulon, J.B.; Faye B. (1995): Predictive model of mastitis occurance in the dairy caw. J. of Dairy Science 78 (10) 2167-2177.

Liebisch, G.; Dorn, H.; Liebisch A. (1994): Control of flies and summer mastitis in grazing cattle by use of cyfluthrin. Societa Italiana di Buiatria volume (1) 765-768.

Misra, P.R. and Panda, S.N. (1986): Some observation on the occurrence of mycotic mastitis in caws in Orissa. Ind. Vet. J. $63: 886$.

Moss, E.S.; and McQuown, A.L. (1979): Atlas of medical mycology. 3rd edition, the Williams and Wilkins company Baltimore.

Naser, M.H. and Abdel Moghney (1994): A field trial for treatment of Mastitis in cattle with Mastipan as an inactivated adjuvanted vaccine. 6th Sci. Cong., Fac., Vet. Med., Assiut, Egypt 492-498. 
Nickerson, S.C.; Owens, W.E.; Boddie, R.L. (1995): Mastitis in dairy heifers; intitial studies on prevalence and control. Journal of Dairy Science 78(7): 1607-1618.

Philip M. Sears (1991): Mastitis control program. Dairy herd managment puplished by the upjohn Company, Lansing. Ny.

Raper, K.B. and Fennel, D.I. (1965): The genus Aspregillus. Baltimore, Willams and Wilkins Company.

Roberson, J.R., Fox, L. K. Hancock; D.D, Gay, J.M. Besser, T.B. (1994): Etiology of staphylococcus aureas isolated from various sites on dairy farms. J. of Dairy Science 77 (11) 3354-3364.

Saxena, R.K.; Dutta, G.N.; Borah P.; Burgohain J. (1993): Drug susceptibility and treatment of bovine mastitis. Indian Vet. J. 70 (3) 201-203.

Schukken Y.H.; Lam, J.G.M.; Nielen M., Hoge Vefxl H. Darrema, H.W. (1993): Subclinical and clinical mastitis in Dutch dary herds; epidemiological developments). Tudschry voor (1995) 120 (7) 208-213 (N1-enz reh) Vet. Faculty. 3508 TD Utrchrt Netherlands.

Smith, K.L. (1983): Mastitis control a discussion. Journal of Dairy Science 66, 1781-1789.

Stokys, J. (1986): Clinical bacteriology 3rd Ed. Eward Arnold London.

Sreeramulu, V.; Ramrao; Gaffar, A.A. (1992): Prevalance of mycotic mastitis in Andra pradesh. Indian Journal of Vet. Med. 12 (2) 68-69.

Untermann, F. (1965): Aetiology of corynebecterium pyogens mastitis. Dt. Tierarztl, Wschr 72, 482-486.

Waage, S.; Aursio, J. (1992): Microorganisms causing mastitis in caws. Meieriposten 18 (12) 337-339.

Yass, A.A. Kara, D.S.; Khalaf, A.M. (1983): Studies on mastitis in buffaloes in Iraq. I prevalence rate and etiology. Tropical Veterinary and Animal Science Research 1 (1) 23-28.

Zaitoun, A.M.; Ali, H.S.; Ahmed, SH.M. and Mourad, M.J. (1991): Bovine mycotic mastitis in upper Egypt. First Scientific Congress; Egyptian Society for cattle diseases, p. 131, 136. 
Assiut Vet. Med. J. Vol. 36 No. 71, October 1996
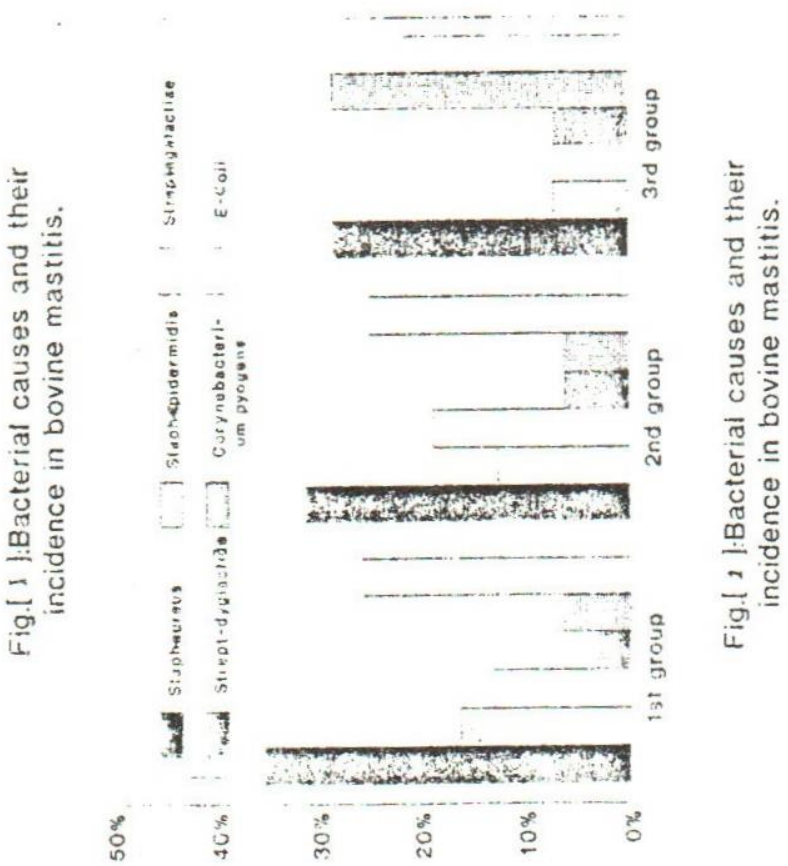

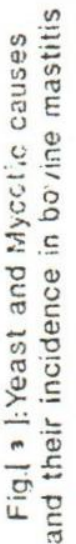

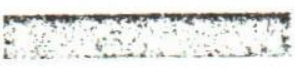

7.
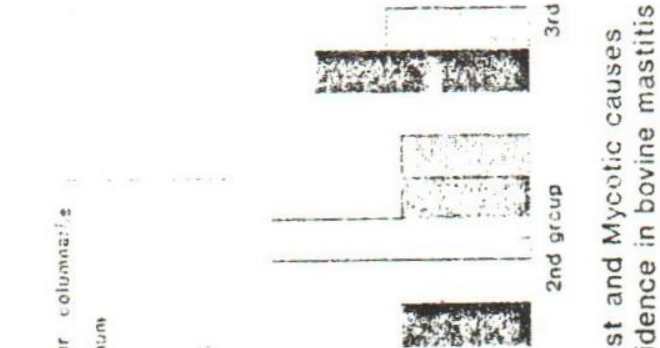

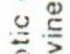

욱

$$
\begin{aligned}
& 0 \\
& 0 \\
& 0 \\
& 0 \\
& 0 \\
& 0 \\
& 0 \\
& 0 \\
& 0 \\
& 0 \\
& 0 \\
& 0
\end{aligned}
$$

긱

网

3.

ํㅗㅇ

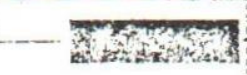

and 3 ,

웅

只

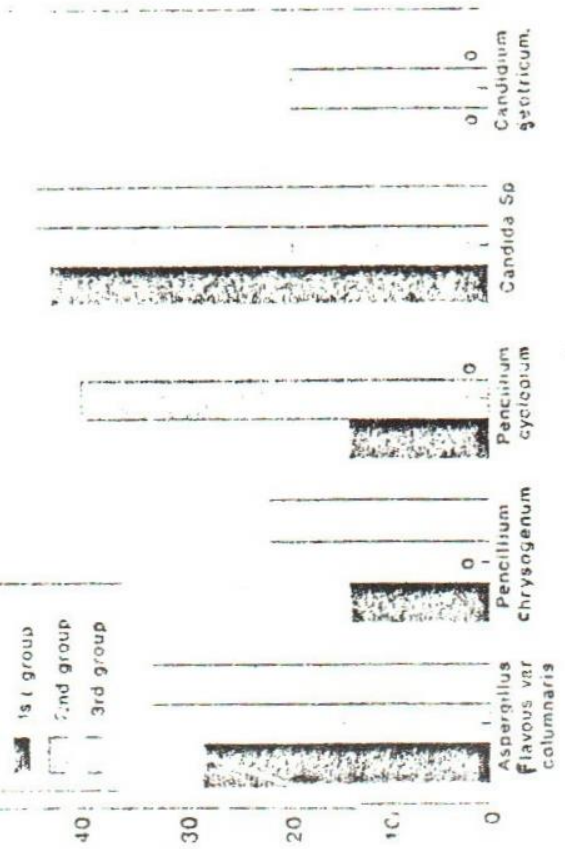



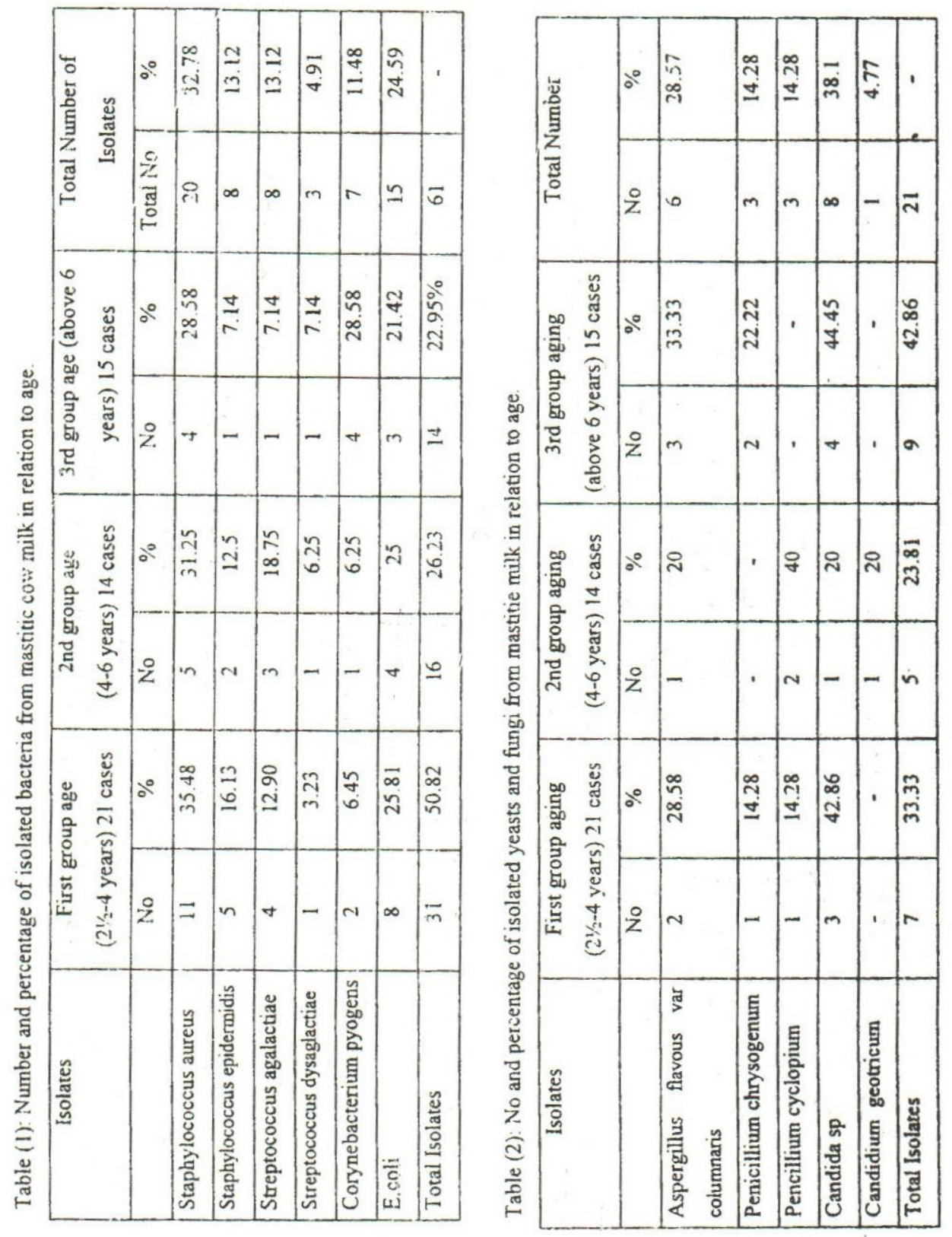

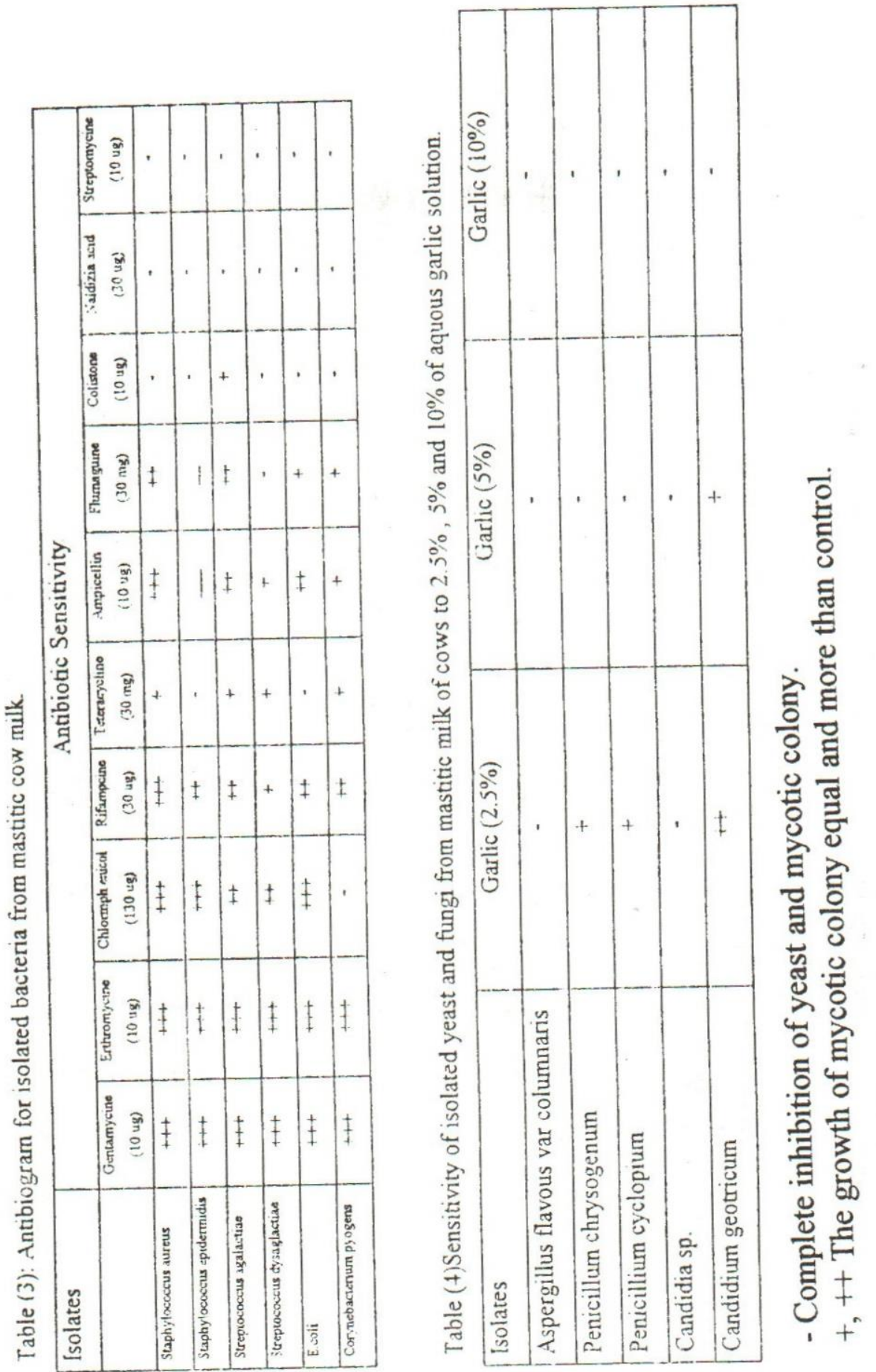